\title{
A STUDY ON THE FACTORS CONSIDERED BY BUYERS WHILE PURCHASING ECO-FRIENDLY HOMES
}

\author{
Mrs. Sanjeevani Pandey
}

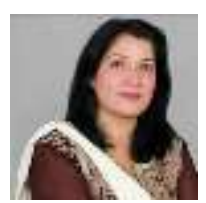

Article DOI: https://doi.org/10.36713/epra7904

DOI No: 10.36713/epra7904

\begin{abstract}
Home buying is a very thought-intensive process that entails several factors like budget, locality, amenities, commutation \& communication facilities etc. Lately, along with these factors, there has been a sought after "Environmental Friendliness \& Sustainability of Homes". People have started looking for properties that are built with a eco-friendly approach, such that it gave rise to a new niche of homes in the arena of homebuying called "Eco-Friendly Houses". An Eco-Friendly House, or an Eco-House as it is called, is basically a low-impact \& environment friendly construction built with the intent of lessening pollution, reducing the carbon footprint, \& thus global warming contribution, of the property, \& having a sustainable endurance.

To study the factors that influence purchase of Eco-Houses, 478 eco-home buyers were interviewed, out of which the researcher with 430 respondents, conducted an empirical study using percentage analysis as a statistical tool and concluded that there are various factors affecting the selection criteria out of which the most effective ones are features of eco-homes like solar energy plants \& wind turbines, rainwater harvesting, planting trees \& saplings all across the premises of then property.
\end{abstract}

\section{INTRODUCTION}

An eco-friendly home, as the name suggests, is environment friendly \& low impact construction that is designed to have a minimal impact on our planet. The trend of eco-homes emerged as a remedy to the climate change that is caused by construction activities \& heat liberation from homes. Eco-friendly houses function around the notion of using renewable sources of energy, optimal energy efficiency \& using natural yet sustainable materials.

Some people might perceive an eco-home as an infrastructurally impaired construction, built with woods \& surrounded by lushed greenery all around. However, contradictory to this perception, an ecohome is a smart \& sustainable building, which is very meticulously planned in order to have minimal effects on the environment.

Some features that characterise eco-friendly homes as sustainable $\&$ smart are as follows

- These homes have higher levels of thermal insulation as compared to conventional houses

- They have Better levels of daylight

- Better air-tightness
- These homes include amenities like a vegetable patch outside the house for growing some organic food

- Minimum north-facing glazing that reduces loss of heat

- Thermal mass that is functional in the absorption of solar heat

- Eco-houses also include Mechanical ventilation with heat recovery (MVHR) system

- Passive solar orientation, which means that the glazing is oriented south for light and heat

- Photovoltaic panels, small wind turbine or electricity from a 'green' supplier

- Natural materials - avoidance of PVCu and other plastics

- Rainwater harvesting

- Composting toilet

- Heating from renewable resources (such as solar, heat pump or biomass)

- Grey-water collection

- Double or triple-glazed windows 
- Geothermal heating and growing plants on the roof to regulate temperature, quieten the house, and to produce oxygen

- Solar panels or wind turbines

\section{LITERATURE REVIEW}

1. "Eco-Friendly Housing Materials- A study with reference to Kerala", a study by Manoj P.K \& Vidya Vishwanath, published in International Journal of Management And Social Science Research Review ; Submitted in September, 2015, Vol I, Issue 15, Page 259-270.

In this research paper, the researchers have done an analytical study taking 11 housing schemes of Kerala on the material used for construction. Apart from that, they have also done a study on the loan proportion given by banks. The paper gives a detail of the proportion of material used in construction along with its composition of expenditures in construction. They concluded that a good eco-housing scheme requires a good financial support system by the banking companies. It also concluded that housing finance system in particular \& favourable macro-economic environment, it appears through promotion of affordable housing in a big way. Apart from a quantum jump in the living of the masses, it ensures a very high level of economic development, with a good prospect to the nation.

2. "Critically Interrogating Eco-Homes", a research paper submitted by Jerry Pickerel in International Journal of Urban and Social Research in May 2017, Vol -41, Issue 2, Pgs 343-355.

In this research paper, the researcher has in detail studied the composition of construction cost including all raw material, labour and other expenses. $\mathrm{He}$ has then analysed upon the materials used for each component in construction and the ways in which construction cost can be reduced. After analysing, concluded that constructing homes using natural resources to make the houses eco-friendly makes the construction cost of the houses, a bit higher than conventional houses.

3. "Construction of Eco Building homes using Green Approach", a research paper submitted by Ashish Kumar Parashar and Rinku Parashar in International Journal of Scientific and Engineering Research, Vol 3, Issue 6, June 2012, Pgs- 1 to 7

The researcher in his paper has studied about the factors for eco-houses and his paper emphasises only on one approach i.e Green approach. The study which was done on Raipur district compared and concluded that the temperature using bara roofs reduced considerably than it was before using Green concept.

The researcher, found a gap in the study of eco friendly homes that no such study was undertaken on the factors influencing buyers decision on purchasing eco friendly homes, hence the study.

\section{OBJECTIVES OF THE STUDY}

1. To study the factors that influence buyers in their selection criteria for Eco-friendly houses in Pune.

2. To study the concept of eco- housing schemes.

3. To give suggestions to the builders to increase the sales of eco-friendly houses.

\section{STATEMENT OF THE PROBLEM}

With the increasing pollution all over the world day by day, health has been an area of concern in the cities. To overcome these issues, eco-housing schemes has emerged as a solution. But what factors are considered by buyers before selection of ecofriendly houses is a problem, hence the study.

\section{HYPOTHESIS}

H1-Solar Energy is the main factor influencing buyers in their selection criteria for Eco-friendly houses.

\section{METHOD OF DATA COLLECTION}

\section{Primary Data}

Primary Data will be collected through structured questionnaire with both close ended and open ended questions

\section{Secondary Data}

Secondary data will be collected from books, research journals, articles, magazines, newspapers, periodicals, related articles, websites, etc.

\section{METHODOLOGY}

The proposed research is an empirical research based on primary data collected from 430 respondents through 478 questionnaires from students of various housing schemes in Pune city.

\section{TECHNIQUES AND STATISTICAL TOOLS}

Being qualitative data, percentage method would be taken to arrive at the importance of factor influencing selection of eco-friendly houses taking 430 respondents of Colleges in Pune city as $100 \%$. 


\section{SCOPE AND LIMITATIONS}

1. The scope is limited to Pune city only.
2. The study of factors influencing the students in selection of Eco-Housing Schemes is only taken into consideration.

3. The sample is limited to 430 respondents.

\section{FINDINGS}

\begin{tabular}{|c|c|c|c|c|}
\hline \multirow[t]{2}{*}{ Factors } & \multicolumn{4}{|c|}{ Response } \\
\hline & Very Important & Important & Not so important & $\begin{array}{l}\text { Not at all } \\
\text { important }\end{array}$ \\
\hline $\begin{array}{l}\text { Rain water } \\
\text { harvesting }\end{array}$ & 89 & 6 & 3 & 1 \\
\hline $\begin{array}{l}\text { Plantations in the } \\
\text { Premises }\end{array}$ & 82 & 8 & 5 & 5 \\
\hline Solar energy & 98 & 1 & 1 & - \\
\hline Garbage Plant & 46 & 34 & 12 & 8 \\
\hline $\begin{array}{l}\text { Good levels of } \\
\text { Daylight }\end{array}$ & 73 & 13 & 10 & 4 \\
\hline $\begin{array}{l}\text { Construction using } \\
\text { Natural Materials }\end{array}$ & 55 & 35 & 7 & 3 \\
\hline Bio-Gas waste & 24 & 25 & 26 & 25 \\
\hline $\begin{array}{l}\text { Composting } \\
\text { Toilets }\end{array}$ & 47 & 13 & 22 & 18 \\
\hline Vegetable Patch & 28 & 22 & 22 & 28 \\
\hline Wind Turbines & - & 13 & 7 & 76 \\
\hline $\begin{array}{l}\text { Glass to prevent } \\
\text { heat loss }\end{array}$ & 14 & 7 & 30 & 49 \\
\hline $\begin{array}{l}\text { Fair Cross- } \\
\text { Ventilation }\end{array}$ & 85 & 14 & - & 1 \\
\hline
\end{tabular}

\section{ANALYSIS AND INTERPRETATIONS}

From the primary survey conducted for the purpose of this research, it is seen that Solar Energy, or presence of solar power plants in the society premises, is the most sought after factors for buyers while purchasing an eco-friendly house. $92 \%$ of respondents regarded this factor as a very important factor in buying eco-homes. A fairly large majority of the population regarded the following factors as very important while buying an eco-friendly home: Rain water harvesting (89\%), plantations \& lushed greenery within the premises $(82 \%)$, fair crossventilation $(85 \%)$, good levels of daylight $(73 \%)$. When it comes to the construction of the building, $55 \%$ of the respondents necessarily take into consideration the use of natural materials, whereas another $35 \%$ take this as an important factor while making a purchase of an eco-house. $47 \%$ people think composting toilets is one of the very important factors while buying eco-friendly homes, whereas $18 \%$ of the population does not deem this as an important factor at all. The presence of vegetable patch is a very important factor for $28 \%$ of people, whereas is not at all important for another $28 \%$ people. The bio-gas waste is a very important factor for $24 \%$ people, important for $25 \%$ people, not so important for $26 \%$ people \& not important at all for
$25 \%$ people. Glasses that prevent heat loss are deemed extremely important by $14 \%$ of the population, important by $7 \%$ population, not so important by $30 \%$ of the population \& not at all important by $49 \%$ of the population.

\section{HYPOTHESIS TESTING}

Using percentage analysis as a tool of statistics and using above interpretations and analysis, we find that it is solar energy having the highest percentage of considering this factor as a very important one, as $98 \%$, we conclude that Solar Energy is the main factor influencing buyers in their selection criteria for Eco-friendly houses. Hence, H1 is accepted

\section{SUGGESTIONS}

The Researcher after analysis and interpretation, has recommended for following suggestion:

In order to increase the sales of the ecofriendly houses, builders must plan a good marketing strategy.

Apart from marketing, builders must try to include the features of solar energy and rain water harvesting as an important feature to attract the potential buyers. 


\section{REFERENCES}

1. https://en.wikipedia.org/wiki/Ecohouse

2. https://www.ovoenergy.com/blog/green/10amazing-eco-friendly-houses.html

3. https://www.whatshot.in/pune/breathable-homesthat-dont-require-ac-or-fans-c-15982

4. http://wildwoods.coleco-friendly-bespoke-homesin-pune.php

5. http://www.ecohomesindia.com/

6. https://www.houzz.in/professionals/pune-1259229/service--eco-homes

7. https://www.proptiger.com/ecohomes-101559

8. https://ecobnb.com/blog/2020/06/building-ecofriendly-housel

9. https://www.propacity.in/blog/green-homes/

10. https://www.2-10.com/blog/explaining-ecofriendly-home-features-buyers-2-10-blog/

11. https://www.ecosustainablehomes.com.au/blog/

12. https://ecofriendlyhouses.blogspot.com/2013/01/ecofriendly-home-plans.html

13. https://www.casagrand.co.in/blog/eco-friendlyhome-maintenancel

14. https://theecologist.org/2012/may/04/five-besteco-friendly-interiors-blogs

15. https://carbontrack.com.au/blog/eco-friendlyhomes/

16. https://elemental.green/the-top-25-green-homebuilding-and-design-websites-to-watch-in-2018/

17. https://www.zameen.com/blog/build-eco-friendlyhome.html

18. https://www.homes247.in/blogs/how-to-create-agreen-home-163

19. https://thedesignfiles.net/feature/sustainablehomes/

20. https://www.leonardleese.com/get-your-homemore-eco-friendly-our-top-tips/eco-friendlyhomes-blog/

21. https://environmental-conscience.com/greenbuilding-pros-cons/

22. https://www.researchgate.net/publication/284273 109

23. https://onlinelibrary.wiley.com/doi/full/10.1111/1 468-2427.12453

24. https://www.ijser.org/researchpaper/Constructio n-of-an-Ecofriendly-Building-using-Green-

Building-Approach.pdf 